18. Цвєткова А., Закорчевна Н. Протокол про воду і здоров'я як інструмент водної безпеки. ECOBUSINESS. Екологія підприємства. 2020. № 2. C. 14-18.

DOI https://doi.org/10.30525/978-9934-26-111-4-25

\title{
ЕКОЛОГІЧНЕ НАВЧАННЯ І ВИХОВАННЯ ЯК СКЛАДОВА ЕВРОПЕЙСЬКИХ СТАНДАРТІВ ПРИ НАВЧАННІ ПРОВІЗОРІВ
}

Хмельникова Л. І.

кандидат хімічних наук, доиент кафедри біохімї та медичної хімї

Дніпровський державний медичний університет

Більчук В. С.

кандидат біологічних наук, викладач кафедри біохімї та медичної хімії Дніпровський державний медичний університет

\section{Слссарчук В. Ю.}

кандидат біологічних наук,

доцент кафедри загальної та клінічної фармациї Дніпровський державний медичний університет м. Дніпро, Україна

В сучасних умовах в результаті стрімкого розвитку промислової індустрії і величезного впливу антропогенного чинника на навколишнє середовище особливо гостро постає питання його охорони, підтримки еволюційно сформованої рівноваги в природі, раціонального використання природних ресурсів. Гармонійна взаємодія суспільства і природи буде тільки в тому випадку, коли наука, техніка і освіта будуть сприяти формуванню нових моральних критеріїв, спрямованих на усвідомлення особистості себе, як активної частини природи, єдності з нею.

Проблема охорони навколишнього середовища переросла в глобальну екологічну проблему, покликану врятувати людство від загрози загального і незворотного забруднення довкілля. Загрозливих масштабів досягло хімічне забруднення не тільки повітряного басейну, а й грунту, річок. Все це веде до різкого зростання захворюваності населення. 
Охорона довкілля - проблема, в першу чергу наукова, медична. У зв'язку з цим, важливе значення має екологічне навчання і виховання фахівців фармацевтичного профілю, які в своїй діяльності безпосередньо пов'язані з використанням природних ресурсів, в тому числі рослинної сировини.

Автори $[1$, с.240] зазначають, що екологічна підготовка студентів повинна доповнюватися екологічним вихованням, в процесі якого відбувається цілеспрямоване формування системи ціннісних орієнтацій, морально - етичних і естетичних стосунків, що забезпечують екологічну відповідальність майбутніх фахівців за дії в місці існування. Такий підхід до досліджуваної проблеми є обгрунтованим, оскільки в процесі навчання одночасно відбувається соціалізація особистості, завдяки якій майбутній випускник засвоює певну систему знань, норм i значущих цінностей через призму екологічної культури, що дозволить йому згодом здійснювати професійну діяльність в якості екологічно компетентного члена суспільства.

Від професіоналізму провізорів, що мають постійний контакт 3 населенням, багато в чому залежить здоров'я нашого суспільства. Порушення генетично обгрунтованих зв'язків людини і навколишньої біосфери є основною причиною виникнення і розвитку різних захворювань. Особливе місце в профілактиці і лікуванні цих захворювань займають лікарські рослини і препарати з них.

3 огляду на проблеми екології, екологічне виховання включаємо в програму навчання студентів хімічним і спеціальним дисциплінам вже 3 першого курсу. Екологічне навчання $\mathrm{i}$ виховання студентів передбачає як аудиторну, так і позааудиторну роботу.

Питання екології та охорони навколишнього середовища широко вивчаються студентами при проходженні хімічних і спеціальних дисциплін. На протязі всього навчання, як на лекціях, так і на практичних заняттях розглядаються питання раціонального використання рослинних ресурсів: заготівля лікарської рослинної сировини; проведення заходів забезпечення отримання доброякісної сировини; освоєння методів хімічного, фізико-хімічного та фітохімічного аналізів, що дозволяють оцінити якість сировини і провести його стандартизацію.

Особлива увага приділяється можливості пізнання студентами під час лабораторних занять прийомів і правил екологічного захисту, збереження ресурсів лікарських рослин, отримання сировини, що не містить токсикантів і радіонуклідів. Щорічно проводимо ділові ігри зі студентами 2 і 3 курсів. Все це дозволяє виховати у студентів широкий 
кругозір, що важливо для них як для майбутніх фахівців і просто освічених людей.

Для формування екологічного мислення велике значення має активна участь студентів в роботі студентського наукового гуртка, 3 якого вийшло чимало студентських робіт 3 природоохоронної тематики, виступами студентів на Всеукраїнських та міжнародних студентських конференціях. Так, за останні три роки прийняли участь у таких конференціях понад 25 студентів -провізорів. Тематика студентських робіт стосувалася ресурсів лікарських рослин в різних районах міста та області. накопичення в них біологічно активних речовин і промислових токсикантів, розробки ресурсозберігаючих технологій при отриманні препаратів з рослин та ін. Роботи студентів неодноразово відзначалися дипломами на Всеукраїнських та міжнародних конференціях, за їх результатами $є$ велика кількість наукових публікацій.

Екологічна освіта, будучи каналом трансляції соціокультурних цінностей, не є засобом формування людини взагалі, вона формує фармацевта в конкретному суспільстві, згідно 3 потребами цього суспільства. Тому саме суспільство в особі працедавців і інших зацікавлених осіб повинно визначати основні соціальні і екологічно значущі вимоги до якості підготовки фармацевта, його компетентності i готовності до майбутньої професійної діяльності. Екологічна компетенція повинна також пронизувати усі ключові компетенції, що формуються на усіх етапах освітнього і виховного процесу, бути інтегративним результатом i загальнокультурним показником. Можна сказати, що екологічна культура $\epsilon$ не окремим видом культури, що регулюється стосунками людини зі світом природи, а вектор усіх складових культури сучасної людини, зокрема соціальної, валеологічної, економічної, здоров’язберігаючої та ін..

Цілеспрямоване використання міждисциплінарних зв'язків в екологічній підготовці роблять вплив на результативність учбового процесу, професійні знання становляться більше узагальненими i комплексними. Враховуючи специфіку фармацевтичної освіти, подібну інтеграцію доцільно починати 3 хімічних дисциплін, які об'єднані загальними матеріальними і фундаментальними законами природи. Формування екологічної компетентності майбутнього фармацевта базується на наступних концептуальних принципах: доцільності, модульності, інтеграційній цілісності, динамічності, дієвості і оперативності знань, гнучкості, усвідомленості перспективи, різного методичного консультування, паритетності. Усі висунені принципи 
системи виховання екологічної компетентності майбутнього фармацевта на основі реалізації інтеграційно-модульної технології взаємопов'язані і відбивають певні особливості побудови змісту екологічного навчання в нових умовах розвитку суспільства.

Придбання необхідних екологічних знань при вивченні хімічних дисциплін, умінь, навичок, що трансформуються в комплекс хімічних компетенцій, як основи майбутнього професіоналізму, створення передумов формування особистісних якостей, які диктуються потребами майбутньої професії - ось, що важливо для підготовки студентів провізорів до їх подальшої навчальної та професійної діяльності.

Як показали опитування студентів про причини їх неуспішності по деяким дисциплінам, поряд з об'єктивними труднощами їх засвоєння величезний вплив відіграє те, що студент часто погано уявляє собі місце і роль вивчаємих дисциплін у майбутній професійній діяльності.

Методичне забезпечення дисципліни для студентів - провізорів розроблено на основі компетентнісного підходу, модульності і послідовності викладання навчального матеріалу, що включає робочу програму, дидактичні та контролюючі матеріали і характеризується повнотою і доступністю інформації. Такий підхід сприяє вирішенню протиріччя між обсягом навчального матеріалу і навчальним часом на його вивчення i визначає для студентів - провізорів кінцеві цілі освоєння хімічних у вигляді компетенцій (екологічних, хімічних, фармакологічних) і напрямки їх досягнення (види, способи діяльності, в тому числі самостійної).

У методичних матеріалах до виконання лабораторних робіт значна увага приділяється профілізації викладання в плані ознайомлення студентів з фармакопейними методиками аналізу різних лікарських речовин. Кожна лабораторна робота виконується як індивідуальне навчально - дослідне завдання, що дозволяє найбільш об'єктивно оцінювати практичні навички студента - провізора. Методичні рекомендації щодо організації самостійної роботи спрямовані на закріплення вміння пошуку, накопичення та обробки наукової інформації.

Таким чином, подальша досконалість форм і методів екологічної освіти і виховання студентів 3 включенням нових інформаційних технологій, поряд зі розвитком інтеграційних зв'язків теоретичних i спеціальних дисциплін, буде сприяти формуванню у майбутніх провізорів екологічного мислення та екологічної культури, що є одним 3 необхідних умов формування глибоких професійних знань, умінь i навичок у студентів-провізорів $\mathrm{i}$, що дуже важливо, розуміння 
регіональних особливостей стану здоров'я населення. Підвищення якості підготовки фахівця неможливо без взаємозв'язку хімічних і фармацевтичних дисциплін, їх інтеграції в процесі навчально пізнавальної та науково - дослідницької діяльності студентів, важливих для формування їх наукового світогляду і хіміко фармацевтичної культури.

\section{Література:}

1. Duca Gh. Dicţionar poliglot de chimie ecologică. / Gh. Duca // Chisinau: Inst. de Studii Enciclopedice.- 2012. - 680 p. 